\title{
Discovery of Unusual Cyanobacterial Tryptophan-Containing Anabaenopeptins by MS/MS-Based Molecular Networking
}

\author{
Subhasish Saha ${ }^{1,+}$, Germana Esposito ${ }^{2,+} \mathbb{D}$, Petra Urajová ${ }^{1}$, Jan Mareš ${ }^{1,3}$, Daniela Ewe ${ }^{1}$, \\ Alessia Caso ${ }^{2} \mathbb{D}$, Markéta Macho ${ }^{1,4}$, Kateřina Delawská 1,4, Andreja Kust 1,3 ${ }^{\mathbb{D}}$, Pavel Hrouzek ${ }^{1}$, \\ Josef Jurán̆ $^{4,5}$, Valeria Costantino ${ }^{2, *(D)}$ and Kumar Saurav ${ }^{1, *(D)}$ \\ 1 Laboratory of Algal Biotechnology-Centre Algatech, Institute of Microbiology of the Czech Academy \\ of Sciences, 37981 Třeboň, Czech Republic; saha@alga.cz (S.S.); urajova@alga.cz (P.U.); mares@alga.cz (J.M.); \\ ewe@alga.cz (D.E.); macho@alga.cz (M.M.); delawska@alga.cz (K.D.); kust@alga.cz (A.K.); \\ hrouzek@alga.cz (P.H.) \\ 2 Task Force Big Fed2, The Blue Chemistry lab, Università degli Studi di Napoli, 80131 Napoli, Italy; \\ germana.esposito@unina.it (G.E.); alessia.caso@unina.it (A.C.) \\ 3 Institute of Hydrobiology, Biology Centre of the Czech Academy of Sciences, \\ 37005 České Budějovice, Czech Republic \\ 4 Faculty of Science, University of South Bohemia in České Budějovice, Branišovská 1760, \\ 37005 České Budějovice, Czech Republic; josef.juran@ibot.cas.cz \\ 5 Institute of Botany of the Czech Academy of Sciences, 25243 Průhonice, Czech Republic \\ * Correspondence: valeria.costantino@unina.it (V.C.); saurav@alga.cz (K.S.); Tel.: +420-737-003-359 (K.S.) \\ + These authors contributed equally to this work.
}

Academic Editor: Derek J. McPhee

Received: 21 July 2020; Accepted: 19 August 2020; Published: 20 August 2020

\begin{abstract}
Heterocytous cyanobacteria are among the most prolific sources of bioactive secondary metabolites, including anabaenopeptins (APTs). A terrestrial filamentous Brasilonema sp. CT11 collected in Costa Rica bamboo forest as a black mat, was studied using a multidisciplinary approach: genome mining and HPLC-HRMS/MS coupled with bioinformatic analyses. Herein, we report the nearly complete genome consisting of $8.79 \mathrm{Mbp}$ with a GC content of $42.4 \%$. Moreover, we report on three novel tryptophan-containing APTs; anabaenopeptin 788 (1), anabaenopeptin 802 (2), and anabaenopeptin 816 (3). Furthermore, the structure of two homologues, i.e., anabaenopeptin 802 (2a) and anabaenopeptin 802 (2b), was determined by spectroscopic analysis (NMR and MS). Both compounds were shown to exert weak to moderate antiproliferative activity against HeLa cell lines. This study also provides the unique and diverse potential of biosynthetic gene clusters and an assessment of the predicted chemical space yet to be discovered from this genus.
\end{abstract}

Keywords: Brasilonema; anabaenopeptins; hexapeptides; tryptophan-containing peptides; molecular networking; antiproliferative activity

\section{Introduction}

For 3.5 billion years, cyanobacteria have kept developing new adaptation features and defense mechanisms which allowed them to colonize the earth, shape its atmosphere from anoxic to oxygenic, and ever since to survive in harsh and strongly competitive environments under extreme temperatures, salt stress, high UV-radiation, and pathogen attack [1,2]. One of these survival strategies is the production of a vast variety of secondary metabolites, exhibiting a broad spectrum of biological activities and properties, including peptides, lipopeptides, polyketides, alkaloids, lipids, and terpenoids [3-7]. When growth conditions are advantageous, cyanobacteria proliferate, resulting in overgrown 
populations known as cyanobacterial blooms (CBs), which can be harmful for aquatic life as well as for human health because of the toxins they produce [8,9]. Cyanobacteria comprise a wide range of phylogenetic lineages, of which the monophyletic order Nostocales (heterocytous cyanobacteria) are an extremely competent group in terms of general secondary metabolite production [10]. Filamentous cyanobacteria, in particular the genera Anabaena, Nostoc, Oscillatoria, and Lyngbya, produce a large variety of secondary metabolites, estimated to account for approximately $25 \%$ of the total number of known cyanobacterial metabolites [11-14]. These compounds are usually produced by nonribosomal peptide synthetases (NRPS), polyketide synthases (PKS), or NRPS/PKS hybrid enzymes. Recent advancement in the field of genome sequencing and the rise of fast and extremely accurate analytical methods, such as high-performance liquid chromatography connected to high-resolution mass spectrometry (HPLC-HRMS/MS), have accelerated the discovery of novel secondary metabolites e.g., [5,6,15]. The use of molecular networking as a dereplication strategy allows to identify the complexity of variants produced by respective biosynthetic genes, which in turn produce valuable data for pharmaceutical development, since structural variants often have different biological activities [16-18].

Anabaenopeptins (APTs) are a family of cyclic hexapeptides produced by diverse cyanobacterial taxa, first described from the planktonic representative Anabaena flos-aqae NRC 525-17 [19]. APTs manifest a general structure $X^{1}-\mathrm{CO}-\left[\mathrm{Lys}^{2}-\mathrm{X}^{3}-\mathrm{X}^{4}-\mathrm{Me} \mathrm{X}^{5}-\mathrm{X}^{6}\right]$, wherein the $\mathrm{X} 1$ and $\mathrm{X} 3-6$ can be either non-proteinogenic or proteinogenic amino acids. The cyclization bond is formed between the $C$-terminal carboxyl and the $N$-terminal amine of the conserved D-Lys at position 2 [20]. The exocyclic amino-acid $\mathrm{X} 1$ is connected to the $\alpha$-amino group of the conserved Lys residue via the ureido bond. APTs encoded in the biosynthetic gene cluster first identified from Planktothrix rubescens NIVA CYA 98 [21] are produced by NRPS following a sequential synthesis pathway using (non) proteinogenic amino acids as a substrate [22]. These clusters have been characterized in many strains belonging to various genera such as Anabaena, Nostoc, Nodularia, and Planktothrix [21-24]. Large structural variability is observed among APTs with members exhibiting masses between 679 and $956 \mathrm{Da}$, with various biological activities, including inhibition of protein phosphatase, carboxypeptidases A and $U$, and other protease-inhibitory activity [20]. Since the first study, more than 115 isoforms of APTs have been reported, out of which 104 are produced by cyanobacteria, belonging to the genera Anabaena, Aphanizomenon, Microcystis, Nodularia, Nostoc, Planktothrix, Oscillatoria, Schizothrix and Lyngbya [25].

In the present study, we report the draft genome sequence of a new Brasilonema strain collected in Costa Rica. Furthermore, the combined approach of genome mining and HPLC-HRMS/MS coupled with bioinformatic analyses led us to identify four unusual novel tryptophan-containing APTs showing moderate antiproliferative activity.

\section{Results and Discussion}

Strains belonging to the genus Brasilonema are a good source of diverse secondary metabolites [26]. The genus Brasilonema, belonging to the family Scytonemataceae, are terrestrial filamentous, heterocytous false-branching cyanobacteria previously isolated from subtropical and tropical climate zones [27-29]. To the best of our knowledge, the only tryptophan-containing APTs were detected in 2015 from the genus Brasilonema sp. (CENA360 and CENA382) isolated from Brazilian Atlantic Coastal Forest [30], and a hydroxyl-tryptophan containing APT mozamide A, isolated from Theonellid sponge from Mozambique [31]. In this study, we analyzed a terrestrial filamentous Brasilonema sp. CT11 collected in Costa Rica, as black mat on a bamboo trunk (Figure S1). The crude extract ( 16 mg) was obtained upon one week of cultivation in $300 \mathrm{~mL}$ glass column under continuous light condition and its subsequent solvent extraction. The molecular network formed by GNPS analyses yielded thirty clusters and one hundred and eight single nodes without grouping (Figure S2). To date, $>3000$ million MS/MS spectra from various instruments (e.g., Orbitrap and qTOF) have been searched at GNPS, yielding putative dereplication matches of 7.7 million spectra to more than 35,477 compounds. A schizopeptins-related cluster was present in the network and is shown in Figure 1, forming a cluster representing three nodes with $m / z$ 817.428, $m / z$ 803.418, and $m / z$ 789.398. Furthermore, the manual 
curation and detailed MS/MS spectra study led us to interpret the putative presence of three novel tryptophane-containing APTs: anabaenopeptin $788\left(\mathrm{~m} / z 789.4425[\mathrm{M}+\mathrm{H}]^{+}\right)$, anabaenopeptin 802 $\left(\mathrm{m} / z\right.$ 803.4417 $\left.[\mathrm{M}+\mathrm{H}]^{+}\right)$, and anabaenopeptin $816\left(\mathrm{~m} / z 817.4425[\mathrm{M}+\mathrm{H}]^{+}\right)$. The structures of these compounds were manually curated and postulated in accordance with the fragment ions listed in Table 1.

A

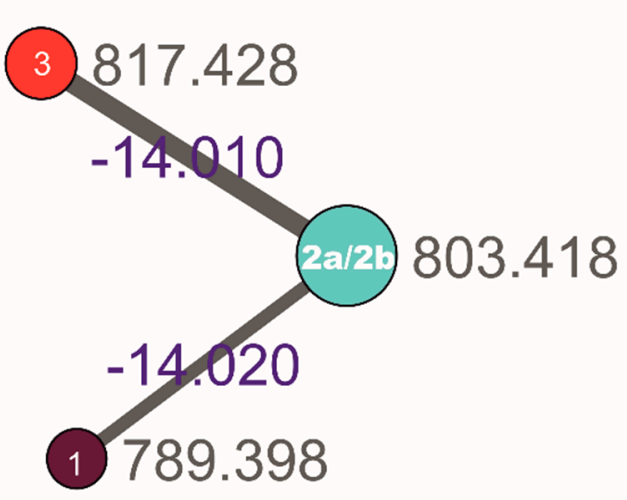

(6)

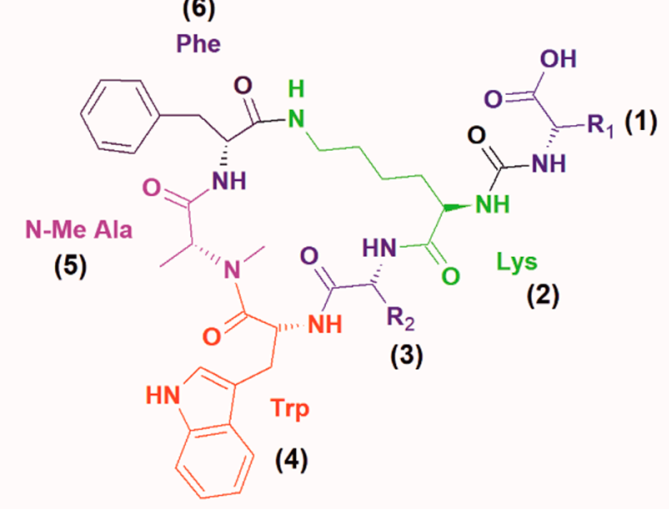

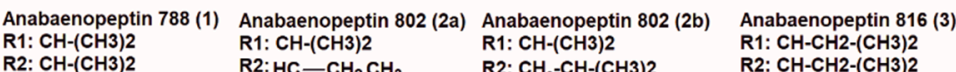

$\stackrel{\mathrm{C}}{\mathrm{C} \mathrm{H}_{3}}$

Figure 1. (A). The molecular network with anabaenopeptins (APT) cluster obtained from the organic extract of Brasilonema sp. CT11. Nodes are labeled with parent $\mathrm{m} / \mathrm{z}$ values and edges with the mass difference. Node size is indicative of the ion count; edge thickness is relative to cosine score. (B). Four APTs detected using LC-HRMS/MS following general structure $X^{1}-\mathrm{CO}-\left[\mathrm{Lys}^{2}-X^{3}-X^{4}-\mathrm{MeX}^{5}-X^{6}\right]$, wherein the $\mathrm{X} 1$ and $\mathrm{X} 3-6$ are non-proteinogenic or proteinogenic amino acids.

Table 1. Product ion spectra data for compounds $\mathbf{1}\left(m / z 789.4425[\mathrm{M}+\mathrm{H}]^{+}\right), 2 \mathrm{a} / \mathbf{2} \mathbf{b}\left(m / z 803.4417[\mathrm{M}+\mathrm{H}]^{+}\right)$, and $3\left(\mathrm{~m} / \mathrm{z} 817.4425[\mathrm{M}+\mathrm{H}]^{+}\right)$.

\begin{tabular}{|c|c|c|c|c|c|c|}
\hline Product Ion Assignment & $1(m / z)$ & Error, ppm & $2 \mathrm{a} / 2 \mathrm{~b}(m / z)$ & Error, ppm & $3(m / z)$ & Error, ppm \\
\hline Lys fragment & 84.0810 & 2.6 & 84.0808 & 0.7 & 84.0808 & 0.2 \\
\hline $\mathrm{MeAla}+\mathrm{CO}+\mathrm{H}^{+}$ & 114.0549 & 0.1 & 114.0551 & 1.1 & 114.0550 & 0.0 \\
\hline Trp fragment & 130.0650 & 0.7 & 130.0653 & 1.0 & 130.0651 & 0.1 \\
\hline Trp-MeAla $+\mathrm{H}^{+}$ & 272.196 & 0.6 & 272.1399 & 2.1 & 272.1394 & 0.6 \\
\hline Trp-MeAla-Val + $\mathrm{H}^{+}$ & 371.2087 & 2.4 & - & & - & \\
\hline Trp-MeAla-Ile/Leu + $\mathrm{H}^{+}$ & - & & 385.2249 & 3.9 & 385.2234 & 0.0 \\
\hline CO-Lys-Phe-MeAla $+\mathrm{H}^{+}$ & 405.2141 & 2.1 & 405.2143 & 2.5 & 405.2138 & 1.4 \\
\hline Val-CO-Lys-Phe-MeAla + $\mathrm{H}^{+}$ & 504.2811 & 1.0 & 504.2830 & 2.7 & & \\
\hline Ile/Leu-CO-Lys-Phe-MeAla $+\mathrm{H}^{+}$ & & & & & 518.2973 & 3.0 \\
\hline Val-CO-Lys-(Val)-(Phe-MeAla) $+\mathrm{H}^{+}$ & 603.3497 & 0.6 & - & & - & \\
\hline Val-CO-Lys-(Ile/Leu)-(Phe-MeAla) + $\mathrm{H}^{+}$ & - & & 617.3677 & 4.0 & - & \\
\hline Ile/Leu-CO-Lys-(Ile/Leu)-(Phe-MeAla) + H & - & & - & & 631.3797 & 2.7 \\
\hline Val-CO-[Lys-Val-Trp-MeAla-Phe] + ${ }^{+}$ & 789.4304 & 1.3 & - & & - & \\
\hline Val-CO-[Lys-Ile/Leu-Trp-MeAla-Phe] + $\mathrm{H}^{+}$ & - & & 803.4469 & 2.3 & - & \\
\hline Ile/Leu-CO-[Lys-Ile/Leu-Trp-MeAla-Phe] + $\mathrm{H}^{+}$ & - & & - & & 817.4612 & 0.6 \\
\hline
\end{tabular}

As a complementary approach to GNPS, we applied whole genome sequencing and subsequent genome mining to investigate the genetic potential of Brasilonema sp. CT11 for the production of secondary metabolites. The newly sequenced draft genome of Brasilonema CT11 (NCBI accession number JABXYX010000000) was retrieved in 411 genomic scaffolds of approximately $8.79 \mathrm{Mbp}$ of total length (99.48\% estimated completeness) and $42.4 \%$ average GC content. The assembly was analyzed for the presence of secondary metabolite biosynthetic gene clusters (BGCs) using antiSMASH 5.1.1. AntiSMASH uses Hidden Markov Models (HMM) and rules-based detection to identify a broad array 
of BGCs, including those encoding polyketide, non-ribosomal peptides, terpenes, aminoglycosides and ribosomally synthesized and post-translationally modified peptides (RiPPs) from bacterial genomes. AntiSMASH predicted 36 putative secondary metabolite clusters from Brasilonema CT11. Out of the 36 gene clusters, four clusters possess 100\% similarity with other known BGCs whereas only two clusters were detected with more than 75\% similarity with known BGCs (Table S1) [32]. Most of these gene clusters were in the NRPS category with 12 recovered BGCs. These putative BGCs yielded hits among various known secondary metabolites showing variable similarity scores, ranging from maximum similarity with known natural product Anabaenopeptin 908/915 (100\%) [22], to minimum similarity with nostocyclopeptide A2 (28\%) [33], suggesting that the pathways may encode new natural products or natural products with no characterized BGCs. Next to NRPS the second most abundant BGCs were NRPS-PKS hybrid (6 clusters), of which one cluster showed 100\% similarity to nostopeptolide A2 [34]. Another interesting hybrid BGC with $60 \%$ similarity to hapalosin BGC [35] was detected, which may lead to the discovery of a new cyclic peptide. Besides these, the other major BGCs detected were: one cluster of PKS type I, three terpenes, two RiPPs, four bacteriocins, and one indole. Among RiPPs class, one lassopeptide and one lantipeptide were detected with no similarity with any reported gene clusters. The PKS type I gene cluster, Merocyclophane C/D [36] was detected with highest similarity of 22\%, which is particularly interesting precisely because of its low similarity. Production of a vast arsenal of secondary metabolites detected in Brasilonemma CT11 is in agreement with the large variety of peptides reported in other Brasilonemma strains as well as related branched cyanobacteria of genus Scytonema [20]. However, to the best of our knowledge no data on secondary metabolites production are available for related genera Symphonemopsis and Symphonema which makes the comparison impossible.

The discovery of a complete putative APT BGC (NCBI accession number MT670293) along with the detection of unusual Trp-containing APT variants using MS/MS networking coupled with manual curation encouraged us to investigate this gene cluster in detail. The putative APT BGC was nearly $25 \mathrm{kbp}$ long and consisted of five genes (aptA-E), clearly homologous to previously reported apt genes (Table S2., [23,25]), and a single short hypothetical open reading frame (Figure 2). Adenylation domains (A-domains) present in the six encoded NRPS modules (Table S3) showed predicted substrate specificities that were in agreement with the amino-acid residues observed in the APT variants detected herein (Figure 3, Table 1), including an unequivocally predicted Trp residue at position 4 of the peptide cycle. Intriguingly, in silico substrate prediction for the starter A-domain $\left(\mathrm{A}_{0}\right)$ and the third A-domain $\left(\mathrm{A}_{2}\right)$ reported only a broad specificity to hydrophobic aliphatic amino acids, with Val, Leu, and Ile among the most probable candidates based on algorithms implemented in antiSMASH. These results are in line with the observed substrate promiscuity, yielding APT variants having either Val or Leu at position 1 and Ile, Leu, or Val at position 3. Previous reports have indicated both substrate promiscuity and occurrence of alternative starter modules to be responsible for variability in amino acids incorporated into APTs [22,23], however we have not detected any additional alternative starter module in our genomic scaffold. The genomic data suggest $\mathrm{D}$-Lys based on the presence of an epimerase (E) domain in the corresponding biosynthetic NRPS module, the remaining amino acids are predicted to be L-enantiomers (Figure 2).

Furthermore, fractionation and manual curation of the spectra suggested to us the presence of four unusual tryptophan-containing anabaenopeptins (two homologues with $\mathrm{m} / \mathrm{z} 803.4417[\mathrm{M}+\mathrm{H}]^{+}$, and $803.4425[\mathrm{M}+\mathrm{H}]^{+}$, one having $m / z 789.4425[\mathrm{M}+\mathrm{H}]^{+}$and one with $m / z 817.4425[\mathrm{M}+\mathrm{H}]^{+}$) using LC-HRMS/MS. The structures of these compounds were postulated in accordance with the fragment ions listed in Table 1 and product ion spectra depicted in Figure 3. Subsequent chromatographical separation led us to isolate two homologues with $m / z 803.44[\mathrm{M}+\mathrm{H}]^{+}, \mathbf{2 a}(0.6 \mathrm{mg})$ and $\mathbf{2 b}(2.6 \mathrm{mg})$. 


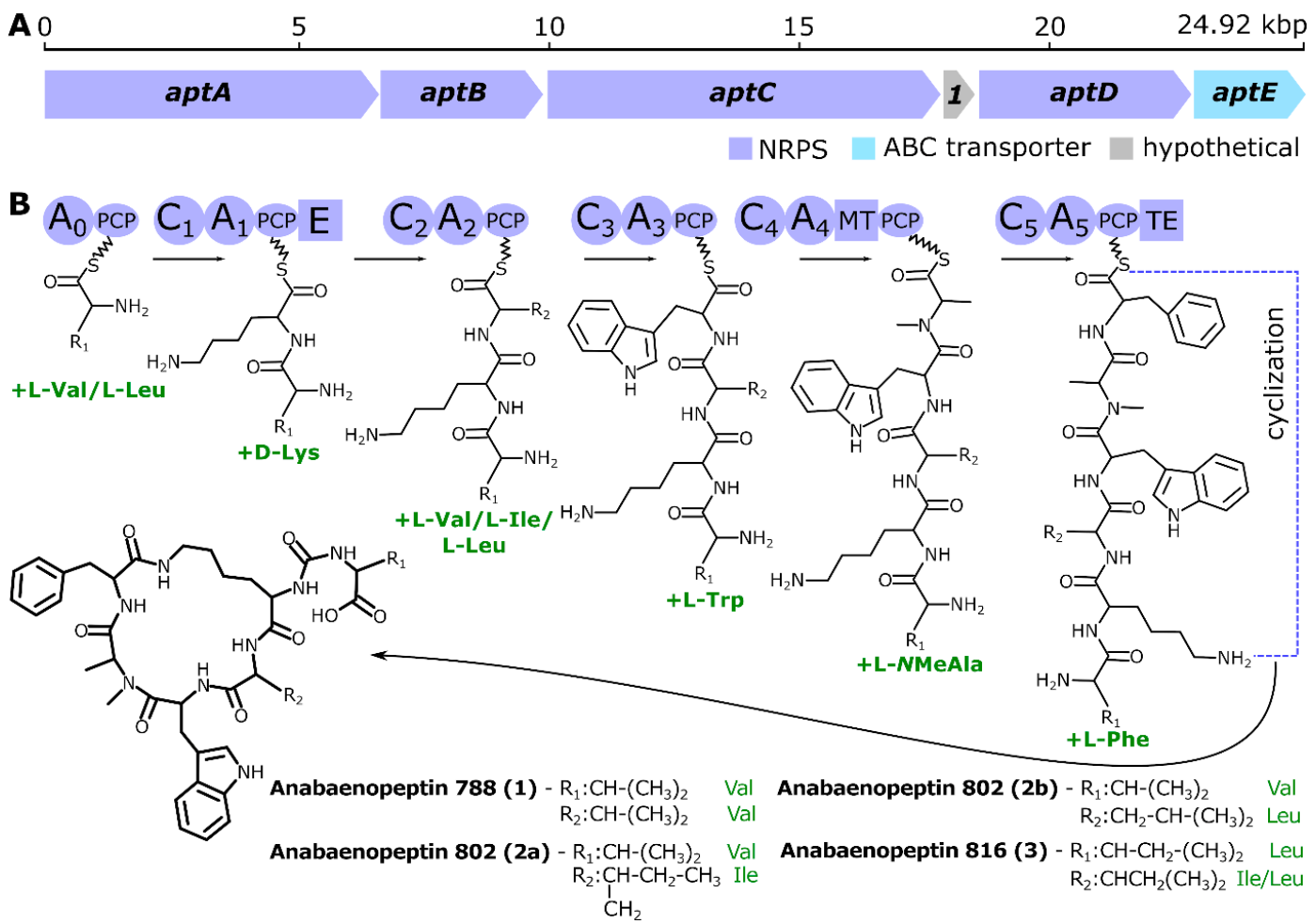

Figure 2. Anabaenopeptin synthetase gene cluster arrangement of Brasilonema CT11 yielding four anabaenopeptins 1, 2a, 2b, and 3. (A) Gene map of the apt biosynthetic gene cluster. (B) Proposed biosynthesis of anabaenopeptins in Brasilonema sp. CT11. A-adenylation domain; C-condensation domain; E-epimerization domain; MT—methyltransferase domain; PCP—peptidylcarrier protein; TE-thioesterase domain.
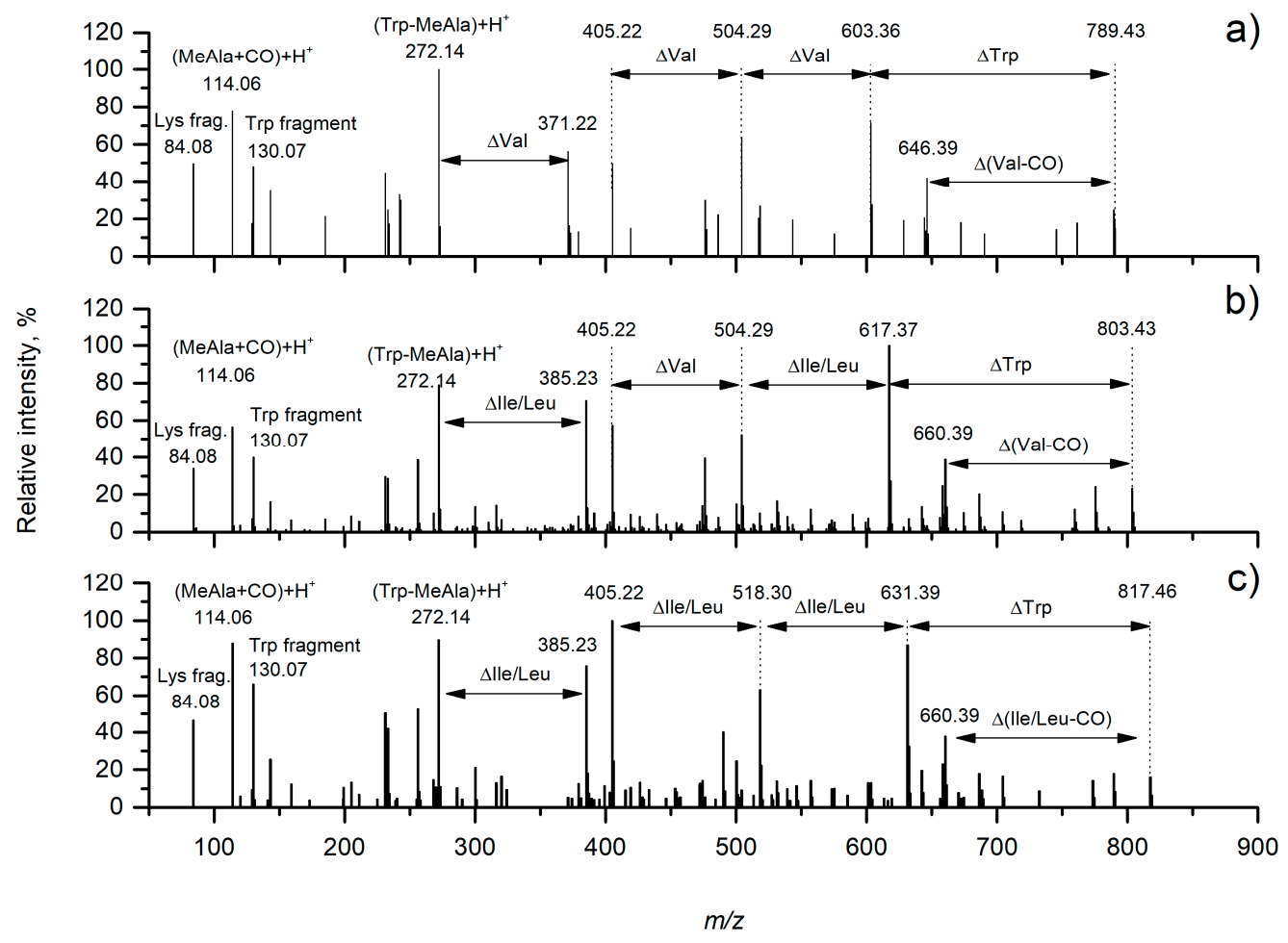

Figure 3. HR-MS/MS product ion spectra of protonated anabaenopeptins from Brasilonema CT11; (a) compound $\mathbf{1}$, (b) compound $\mathbf{2 a} \mathbf{2} \mathbf{2 b}$, and (c) compound 3. 
The HR-ESI-MS mass spectrum of compounds $\mathbf{2} \mathbf{a}$ and $\mathbf{2} \mathbf{b}$ showed $[\mathrm{M}+\mathrm{H}]^{+}$pseudomolecular ion peaks at $m / z 803.4417$ and 803.4425 respectively, which defined its molecular formula as $\mathrm{C}_{42} \mathrm{H}_{58} \mathrm{~N}_{8} \mathrm{O}_{8}$. Their MS/MS spectra were identical. The fragmentation pattern was indicative of two cyclic peptide compounds, with fragments $m / z 504.28$ which indicated the presence of Val at position 1, Lys at position 2, MeAla at position 5, and Phe at position 6; and $\mathrm{m} / \mathrm{z}$ 385. 22 which indicated the presence of Ile/Leu at position 3, and Trp at position 4. Binding of leucine or isoleucine cannot be distinguished by conventional mass spectrometry HPLC-purification was therefore performed to obtain two compounds in pure state. The structures of both homologues were confirmed by extensive NMR analysis. A full set of homonuclear and heteronuclear two-dimensional NMR spectra (COSY, NOESY, HSQC, and HMBC) was recorded (Tables S4 and S5, Figures S4-S15). In particular, the proton spectra showed seven amide $\mathrm{NH}$ signals and six different $\alpha$-proton signals, as expected for a hexapeptide with a $N$-methyl alanine, a lysine, and a tryptophan residue. Analysis of the TOCSY spectrum (Figure S9 and S15) showed correlation of all the protons of the six side chains with the corresponding $\alpha$-proton. This information combined with that derived from the analysis of COSY, HMBC, and NOESY spectra confirmed the structures of compounds $\mathbf{2} \mathbf{a}$ and $\mathbf{2} \mathbf{b}$, and the analysis of COSY spectra led to distinguish the presence of an isoleucine and a leucine residue in compound $\mathbf{2} \mathbf{a}$ and $\mathbf{2} \mathbf{b}$ respectively (Figure 4 ).

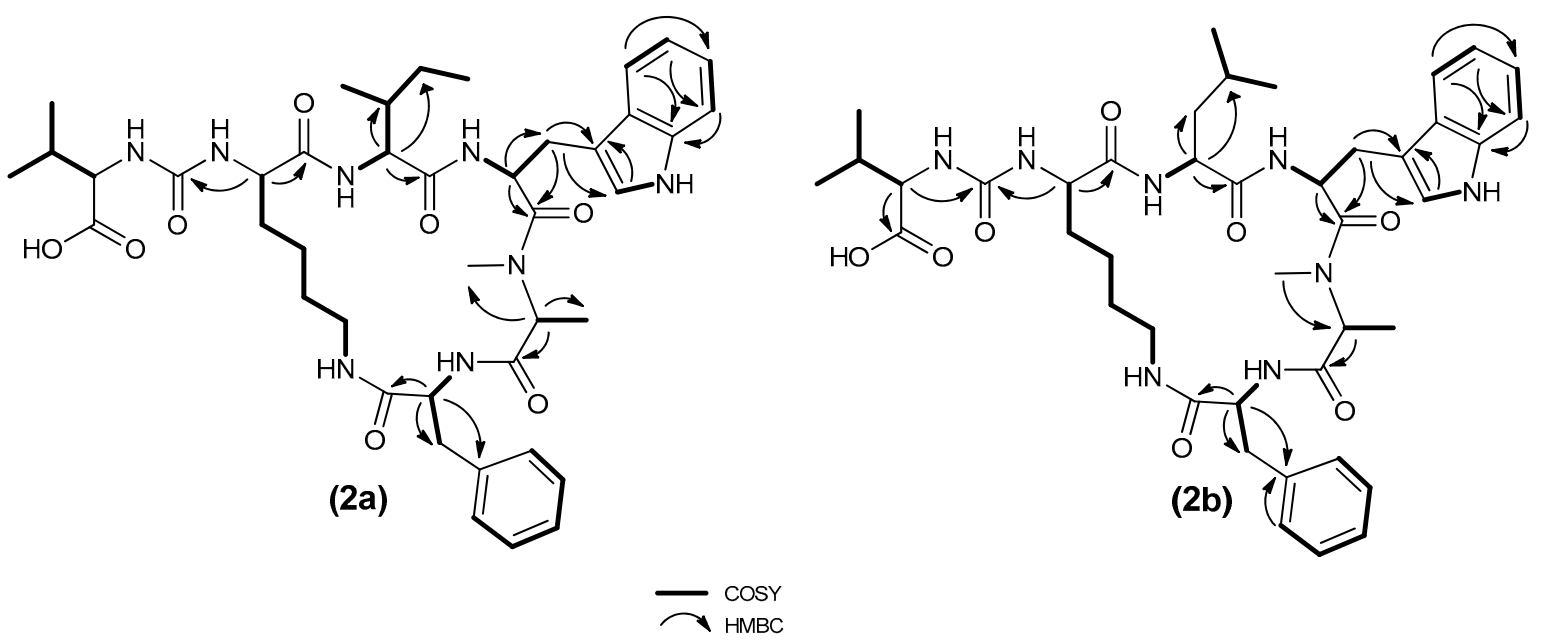

Figure 4. Most significant correlations provided by COSY and HMBC 2D spectra of compounds 2a and $\mathbf{2 b}$.

Taken together, MS evidence, ${ }^{1} \mathrm{H}-\mathrm{NMR}$ and 2D-NMR data, allowed the identification of compounds $\mathbf{2 a}$ and $\mathbf{2 b}$, designated as anabaenopeptin 802a and anabaenopeptin 802 b, respectively (Figure 4). The elucidated structure indicated that compounds $\mathbf{2 a}$ and $\mathbf{2 b}$ are structurally identical to the compounds reported previously [30]. However, the complete structural elucidation using NMR spectroscopy and its biological activity determination is reported now for the first time.

The viability assay was performed on HeLa cells after $48 \mathrm{~h}$ of exposure time (Figure 5). The results show differences between the effectiveness of two structural variants $\mathbf{2 a}$ and $\mathbf{2} \mathbf{b}$. $\mathbf{2} \mathbf{a}$ exhibited a slightly stronger cytostatic effect at concentrations 20,10 and $5 \mu \mathrm{M}$ than $\mathbf{2 b}$. There was no significant difference observed between the effectivity of both the compounds at lower concentrations $(2.5,1.25$ and $0.625 \mu \mathrm{M}$ ) with no decrease in viability (data not shown). These results suggest that even the small conformational change due to the occurrence of alternative starter modules in APTs BGC can influence the effectiveness of the compounds against cancer cells. Substitutions of the amino acid residues are thought to determine the degree of bioactivity $[37,38]$. However, more detailed studies on Trp-containing APTs are needed to establish the structure activity relationship. 


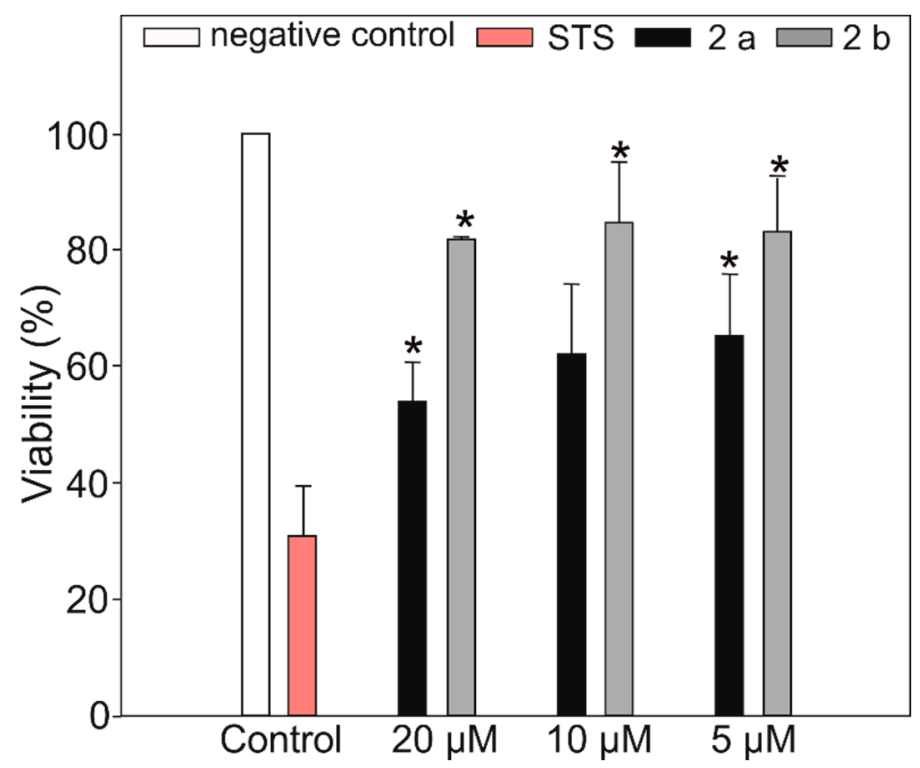

Figure 5. Cell viability was assessed by MTT assay at $48 \mathrm{~h}$ exposure time. Cell viability was calculated as the percentage of viable cells in $\mathbf{2} \mathbf{a}$ and $\mathbf{2} \mathbf{b}$ compounds-treated cells relative to control at 20 , 10 , and $5 \mu \mathrm{M}$ concentration. Data are presented as mean $\pm \mathrm{SD} ; n=3$. ${ }^{*} p \leq 0.05$. STS stands for Staurosporine, used as positive control at $1 \mu \mathrm{M}$ concentration.

\section{Materials and Methods}

\subsection{Cyanobacterial Strain and Culturing Conditions}

The Brasilonema strain was collected in Costa Rica, as black mat on a bamboo trunk, on March 18, 2010 by Jan Mareš and isolated into culture by Josef Juráň. Strain was grown in Z' medium in glass columns $(300 \mathrm{~mL})$ bubbled with air enriched in $1.5 \% \mathrm{CO}_{2}$ at constant temperature and illumination of $28^{\circ} \mathrm{C}$ and $50 \mu \mathrm{mol}$ photon $\mathrm{m}^{-2} \mathrm{~s}^{-1}$ [5]. Biomass was harvested by centrifugation (3125× $g$ ), stored at $-80^{\circ} \mathrm{C}$, and subsequently lyophilized.

\subsection{Genome Sequencing, Assembling, Annotation, and Mining for Identification of Anabaenopeptin Gene Cluster}

Single filaments of Brasilonema sp. CT11 were isolated by glass capillary technique described previously [39]. Briefly, filaments were serially washed in ten drops of TE buffer and amplified by multiple-displacement amplification (MDA) using the Repli-G Mini Kit (Qiagen). Ten filaments that passed quality check by $16 \mathrm{~S}$ rRNA sequencing, were pooled together and sent for commercial de novo genome sequencing (EMBL Genomics Core Facility, Heidelberg, Germany) using an Illumina MiSeq Pair-End library with $250 \mathrm{bp}$ reads, $350 \mathrm{bp}$ average insert length, and $1.4 \mathrm{Gbp}$ data yield. The data from Illumina were assembled using SPAdes 3.14 de novo assembler [40] with the single cell option enabled protein coding genes were predicted using Prodigal in the assembled scaffolds longer than $999 \mathrm{bp}$. All predicted proteins were compared to the NCBI-nr database using MMSeqs26 and only contigs that had the most hits to the cyanobacteria were kept for the rest of the analysis. Completeness of the cyanobacterial bin was estimated using CheckM [41]. The anabaenopeptin gene cluster was identified based on BLASTp searches against the Brasilonema sp. CT11 genome assembly, using previously published apt genes as queries. Predicted open reading frames in the target genomic scaffold were translated and subjected to BLASTp, NCBI conserved-domain search and antiSMASH 5.0 [32] analysis for functional annotation. 


\subsection{Crude Extract Preparation}

Lyophilized biomass ( 100 mg) was grinded (with sea sand) and extracted with $10 \mathrm{~mL}$ of following solvents; hexane, chloroform, chloroform: methanol (1:1) and 70\% methanol in water. All the extractions with different solvents were done in separate batches. Extracts were sonicated for $10 \mathrm{~min}$ (ultrasonication bath) and filtered through glass microfiber filter $(1.2 \mu \mathrm{m})$. All filtrates containing organic phase solvents were evaporated under vacuum using a rotary vacuum evaporator (Laborota 4002, Heidolph, Germany)

\subsection{HPLC-HRMS/MS Analysis}

Crude extract $(1 \mathrm{mg} / \mathrm{mL}$ ) was subjected to C-18 reversed-phase column chromatography on Thermo Scientific DionexUltiMate 3000 UHPLC (Thermo Fisher Scientific, Waltham, MA, USA) equipped with a diode array detector (DAD) and high-resolution mass spectrometry with electrospray ionization source (ESI-HRMS; Impact HD Mass Spectrometer, Bruker, Billerica, MA, USA). HPLC separation was performed on reversed phase Kinetex Phenomenex $C_{18}$ column $(150 \times 4.6 \mathrm{~mm}, 2.6 \mu \mathrm{m})$ with $\mathrm{H}_{2} \mathrm{O}$ /acetonitrile acidified with $0.1 \% \mathrm{HCOOH}$ as a mobile phase. Flow rate during analysis was $0.6 \mathrm{~mL} / \mathrm{min}$. The gradient was as follows: $\mathrm{H}_{2} \mathrm{O} /$ acetonitrile 85/15 (0 min), 85/15 (in $\left.1 \mathrm{~min}\right)$, 0/100 (in $20 \mathrm{~min}$.), 0/100 (in $25 \mathrm{~min}$.), and 85/15 (in $30 \mathrm{~min}$.). The HPLC was connected to a high-resolution mass spectrometer (Bruker Impact HD) with following settings: dry temperature $200{ }^{\circ} \mathrm{C}$; drying gas flow $12 \mathrm{~L} / \mathrm{min}$; nebulizer 3 bar; capillary voltage $4500 \mathrm{~V}$; endplate offset $500 \mathrm{~V}$. The spectra were collected in the range $20-2000 \mathrm{~m} / \mathrm{z}$ with spectra rate $2 \mathrm{~Hz}$. The CID was set as a ramp from 20 to $60 \mathrm{eV}$ on masses 200-1200, respectively. Calibration was performed using LockMass 622 as internal calibration solution and $\mathrm{CH}_{3} \mathrm{COONa}$ at the beginning of each analysis.

\subsection{Molecular Networking}

The raw analytical data were elaborated and studied using molecular networking (Global natural product social networking, GNPS). The raw data were converted to mzXML format using MSConvert from the ProteoWizard suite (http://proteowizard.sourceforge.net/tools.shtml) [42]. The molecular network was created using the Global Natural Products Social Molecular Networking (GNPS) online workflow [43]. The data were filtered by removing all MS/MS peaks within +/- 17 Da of the precursor $m / z$. MS/MS spectra were window-filtered by choosing only the top six peaks in the $+/-$ 50 Da window throughout the spectrum. The data were then clustered with MS-Cluster with a parent mass tolerance of 0.1 Da and a MS/MS fragment ion tolerance of 0.025 Da to create consensus spectra. Consensus spectra containing less than 2 spectra were discarded. A network was then created where edges were filtered to have a cosine score above 0.65 and more than four matched peaks. Edges between two nodes were kept in the network if and only if each of the nodes appeared in each other's respective top 10 most similar nodes. The spectra in the network were then searched against GNPS' spectral libraries. The library spectra were filtered in the same manner as the input data. All matches kept between network spectra and library spectra were required to have a score above 0.7 and at least four matched peaks. Analogue search was enabled against the library with a maximum mass shift of 200 Da.

\subsection{Isolation of Compound $2 \boldsymbol{a}$ and $\mathbf{2} \boldsymbol{b}$ from Brasilonema CT11}

In order to obtain larger biomass volume, the strain was cultivated in $100 \mathrm{~L}$ cultivation unit twice to obtain $30 \mathrm{~g}$ of freeze-dried biomass. Crude extract was prepared as described previously in Section 3.2 to obtain $5 \mathrm{~g}$ of crude extract. The obtained crude extracts were fractionated using reversed-phase flash column chromatography, eluting with a mixture of $\mathrm{H}_{2} \mathrm{O} / \mathrm{CH}_{3} \mathrm{CN}$ (from 0 to $100 \%$ ) and then with $100 \%$ of $\mathrm{MeOH}$, to afford twenty fractions (Fr1-Fr20) [44]. Fraction 15 eluting with $80 \%$ of $\mathrm{CH}_{3} \mathrm{CN}$ was found to be enriched with APT compounds and hence, was further fractionated using Sephadex $\mathrm{LH} 20$ to obtain ten fractions using $\mathrm{CH}_{3} \mathrm{Cl}_{2} / \mathrm{MeOH}$ (1:1). Fraction 3 was further purified using 


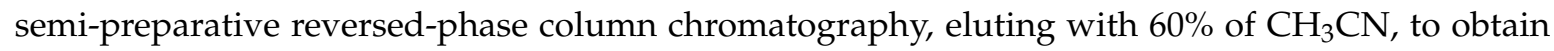
compounds $\mathbf{2 a}$ and $\mathbf{2 b}$.

Compound (2a) HRESIMS: $\mathrm{tR}=20 \mathrm{~min} ;[\mathrm{M}+\mathrm{H}]^{+} \mathrm{m} / \mathrm{z}$ 803.4520, calcd. 803.4411 (Figure S3); ${ }^{1} \mathrm{H}$ NMR (700 MHz, CD3OD): $\delta 9.21(1 \mathrm{H}, \mathrm{d}, J=8.8), \delta 8.97(1 \mathrm{H}, \mathrm{d}, J=3.2), \delta 8.40(2 \mathrm{H}, \mathrm{br} \mathrm{s}), \delta 7.90(1 \mathrm{H}, \mathrm{s})$, $\delta 7.82(1 \mathrm{H}, \mathrm{d}, J=8.0), \delta 7.78(1 \mathrm{H}, \mathrm{br} \mathrm{s}), \delta 7.57(1 \mathrm{H}, \mathrm{d}, J=7.9), \delta 7.31(1 \mathrm{H}, \mathrm{d}, J=8.1), \delta 7.21(2 \mathrm{H}, \mathrm{t}, J=7.6)$, $\delta 7.14(1 \mathrm{H}, \mathrm{t}, 7.6), \delta 7.11(2 \mathrm{H}, \mathrm{d}, J=7.6), \delta 7.09(1 \mathrm{H}, \mathrm{br} \mathrm{d}, J=7.6), \delta 7.05(1 \mathrm{H}, \mathrm{s}), \delta 7.02(1 \mathrm{H}, \mathrm{t}, J=7.4)$, $\delta 5.05(1 \mathrm{H}, \mathrm{dt}, J=11.2,5.0,3.7), \delta 4.60(1 \mathrm{H}, \mathrm{q}, J=6.7), \delta 4.50(1 \mathrm{H}, \mathrm{ddd}, J=12.5,8.7,2.9), \delta 4.18(1 \mathrm{H}, \mathrm{br} \mathrm{s})$, $\delta 4.15(1 \mathrm{H}, \mathrm{t}, J=4.6), \delta 4.04(1 \mathrm{H}, \mathrm{dd}, J=9.6,4.9), \delta 3.75(1 \mathrm{H}, \mathrm{m}), \delta 3.38(1 \mathrm{H}, \mathrm{dd}, J=13.7,3.1)$, $\delta 3.27(2 \mathrm{H}, \mathrm{m}), \delta 2.92(1 \mathrm{H}, \mathrm{br} \mathrm{d}, J=12.6), \delta 2.86(1 \mathrm{H}, \mathrm{t}, J=13.2), \delta 2.25(1 \mathrm{H}, \mathrm{m}), \delta 1.96(1 \mathrm{H}, \mathrm{m}), \delta 1.93$ $(1 \mathrm{H}, \mathrm{m}), \delta 1.75(1 \mathrm{H}, \mathrm{m}), \delta 1.57(3 \mathrm{H}, \mathrm{s}), \delta 1.51(2 \mathrm{H}, \mathrm{m}), \delta 1.45(1 \mathrm{H}, \mathrm{m}), \delta 1.38(2 \mathrm{H}, \mathrm{m}), \delta 1.26(1 \mathrm{H}, \mathrm{m})$, $\delta 1.17(3 \mathrm{H}, \mathrm{d}, J=6.8), \delta 0.98(3 \mathrm{H}, \mathrm{d}, J=6.9), \delta 0.93(3 \mathrm{H}, \mathrm{t}, J=7.4), \delta 0.26(3 \mathrm{H}, \mathrm{d}, J=6.7)$.

Compound (2b): HRESIMS: $\mathrm{tR}=20 \mathrm{~min} ;[\mathrm{M}+\mathrm{H}]^{+} \mathrm{m} / \mathrm{z}$ 803.4510, calcd. 803.4411 (Figure S4); ${ }^{1} \mathrm{H}$ NMR (700 MHz, CD $\left.\mathrm{OD}\right): \delta 10.4(1 \mathrm{H}, \mathrm{s}, \mathrm{NH}-\mathrm{Tr} \mathrm{p}), \delta 9.2(1 \mathrm{H}, \mathrm{d}, J=8.7$, Phe-NH), $\delta 9.0(1 \mathrm{H}, \mathrm{d}$, $J=3.4, \mathrm{NH}-\mathrm{Trp}), \delta 8.2(1 \mathrm{H}, \mathrm{br} \mathrm{s}, \mathrm{NH}-\mathrm{Val}, \mathrm{NH}-\mathrm{CO}-2 \mathrm{H}), \delta 7.9(1 \mathrm{H}, \mathrm{d}, J=8.6, \mathrm{NH}-\mathrm{Lys}), \delta 7.7(1 \mathrm{H}, \mathrm{br} \mathrm{s}$, NH-Leu), $\delta 7.6(1 \mathrm{H}, \mathrm{d}, J=8.1), \delta 7.3(1 \mathrm{H}, \mathrm{d}, J=8.1), \delta 7.2(2 \mathrm{H}, \mathrm{t}, J=7.4), \delta 7.14(1 \mathrm{H}, \mathrm{t}, J=7.4), \delta 7.09$ (t, 3H, overlapped), $\delta 7.04(1 \mathrm{H}, \mathrm{s}), \delta 7.0(1 \mathrm{H}, \mathrm{t}, J=7.4), \delta 5.1(1 \mathrm{H}, \mathrm{m}, \mathrm{CH}-\alpha, \operatorname{Trp}), \delta 4.6(1 \mathrm{H}, \mathrm{q}, J=6.7$, CH- $\alpha, \mathrm{NMeAla}), \delta 4.47$ (1H, ddd, $J=3.1,8.5,12.1, \mathrm{CH}-\alpha$ Phe), $\delta 4.3(1 \mathrm{H}, \mathrm{m}, \mathrm{CH}-\alpha, \mathrm{Leu}), \delta 4.2(1 \mathrm{H}, \mathrm{d}$, $J=3.8), \delta 4.16(1 \mathrm{H}, \mathrm{t}, J=4.9, \mathrm{CH}-\alpha, \mathrm{Lys}), \delta 3.8(1 \mathrm{H}, \mathrm{m}), \delta 3.4(1 \mathrm{H}, \mathrm{dd}, J=3.1,13.5), \delta 3.3(1 \mathrm{H}, \mathrm{d}, J=5.1)$, $\delta 2.9(1 \mathrm{H}, \mathrm{br} \mathrm{d}), \delta 2.85(1 \mathrm{H}, \mathrm{t}, J=13.3), \delta 2.25(1 \mathrm{H}, \mathrm{m}), \delta 1.95(1 \mathrm{H}, \mathrm{tt}, J=3.4,13.8), \delta 1.87(1 \mathrm{H}, \mathrm{m}), \delta 1.76$ (2H, overlapped), $\delta 1.73(1 \mathrm{H}$, overlapped $), \delta 1.62(1 \mathrm{H}, \mathrm{m}), \delta 1.58\left(3 \mathrm{H}, \mathrm{s}, \mathrm{N}-\mathrm{CH}_{3}\right), \delta 1.55(1 \mathrm{H}, \mathrm{m}), \delta 1.47$ $(1 \mathrm{H}, \mathrm{m}), \delta 1.27(1 \mathrm{H}, \mathrm{m}), \delta 1.05(3 \mathrm{H}, \mathrm{d}, J=6.4), \delta 1.0(6 \mathrm{H}, \mathrm{dd}, J=1.9,6.6), \delta 0.92(3 \mathrm{H}, \mathrm{d}, J=6.8), \delta 0.25$ $(3 \mathrm{H}, \mathrm{d}, J=6.6)$.

\subsection{Antiproliferative Activity}

The human cervical cancer line HeLa was obtained from Mgr. David Sedlák, Ph.D. (Institute of Molecular Genetics of ASCR, v.v.i. Czech Republic) and were maintained at $37^{\circ} \mathrm{C}$ in a humidified incubator with $5 \% \mathrm{CO}_{2}$. Cells were cultured in DMEM cultivation medium (Gibco Life Technologies) supplemented with 10\% FBS (Gibco Life Technologies), 1\% antibiotics (Gibco Life Technologies), and L-glutamine $2 \mathrm{mM}$ (Gibco Life Technologies). The HeLa cells were plated (transparent 96-well cell culture plate, flat bottom) at a concentration of $1 \times 10^{4}$ cells per well one day prior to cytotoxicity experiment. The exposure solutions were prepared to obtain final concentration of the compounds 20 , $10,5,2.5,1.25$, and $0.625 \mu \mathrm{M}$ per well. Two technical replicates in one experiment were performed and final concentration of DMSO in the tested wells did not exceed 0.5\%. Staurosporine (Sigma, S5921, St. Louis, MO, USA) was used as positive control at $1 \mu \mathrm{M}$ concentration. After $48 \mathrm{~h}$ of incubation MTT assay [45] was performed as the endpoint measurement. Three independent biological experiments were performed for each compound and finally the viability index was expressed as a ratio between the absorbance values of the treated and control cells in percent.

\subsection{Data Deposition}

The strain Brasilonema sp. CT11 has been deposited to culture collection of autotrophic organisms (CCALA) under the strain number CCALA 1130. The genomic assembly is available under NCBI accession number JABXYX010000000, and the anabaenopeptin biosynthetic gene cluster is available under accession number MT670293. The mass spectrometry data was deposited on MassIVE public repository (MSV000085797). The molecular networking job can be publicly accessed at https://gnps. ucsd.edu/ProteoSAFe/status.jsp?task=537f43651a084553ad560eac52895539.

Supplementary Materials: The following are available online.

Author Contributions: Conceptualization, S.S., M.M. and K.S.; Methodology, S.S., K.S., G.E., A.C., J.M. and P.H.; Formal analysis, P.U., J.J., K.S., and J.M.; Investigation, S.S., A.K., K.D., and K.S.; Data curation, J.M., J.J., V.C. and K.S.; Writing—original draft preparation, S.S., D.E., G.E., A.C., J.M., V.C., and K.S.; Writing-review and 
editing, K.S., P.H., and V.C.; Supervision, K.S.; Project administration, K.S.; Funding acquisition, K.S. All authors have read and agreed to the published version of the manuscript.

Funding: This study was supported by the Ministry of Education, Youth and Sports of the Czech Republic MSCA IF II project (CZ.02.2.69/0.0/0.0/18_070/0010493), Czech Science foundation (GAČR- project no. 19-17868Y) and OncoLab, Regione Campania, PO FESR 2014-2020, O.S. 1.2, Project “Campania Oncoterapie” No. B61G18000470007.

Conflicts of Interest: The authors declare no conflict of interest.

\section{References}

1. Mazard, S.; Penesyan, A.; Ostrowski, M.; Paulsen, I.T.; Egan, S. Tiny Microbes with a Big Impact: The Role of Cyanobacteria and Their Metabolites in Shaping Our Future. Mar. Drugs 2016, 14, 97. [CrossRef] [PubMed]

2. Schirrmeister, B.E.; Antonelli, A.; Bagheri, H.C. The origin of multicellularity in cyanobacteria. BMC Evol. Biol. 2011, 11, 45. [CrossRef]

3. Demay, J.; Bernard, C.; Reinhardt, A.; Marie, B. Natural Products from Cyanobacteria: Focus on Beneficial Activities. Mar. Drugs 2019, 17, 320. [CrossRef] [PubMed]

4. Dittmann, E.; Gugger, M.; Sivonen, K.; Fewer, D.P. Natural Product Biosynthetic Diversity and Comparative Genomics of the Cyanobacteria. Trends Microbiol. 2015, 23, 642-652. [CrossRef] [PubMed]

5. Saurav, K.; Macho, M.; Kust, A.; Delawska, K.; Hajek, J.; Hrouzek, P. Antimicrobial activity and bioactive profiling of heterocytous cyanobacterial strains using MS/MS-based molecular networking. Folia Microbiol. (Praha) 2019, 64, 645-654. [CrossRef] [PubMed]

6. Mares, J.; Hajek, J.; Urajova, P.; Kust, A.; Jokela, J.; Saurav, K.; Galica, T.; Capkova, K.; Mattila, A.; Haapaniemi, E.; et al. Alternative Biosynthetic Starter Units Enhance the Structural Diversity of Cyanobacterial Lipopeptides. Appl. Env. Microbiol. 2019, 85. [CrossRef]

7. Kust, A.; Mares, J.; Jokela, J.; Urajova, P.; Hajek, J.; Saurav, K.; Voracova, K.; Fewer, D.P.; Haapaniemi, E.; Permi, P.; et al. Discovery of a Pederin Family Compound in a Nonsymbiotic Bloom-Forming Cyanobacterium. Acs Chem. Biol. 2018, 13, 1123-1129. [CrossRef]

8. Teta, R.; Romano, V.; Sala, G.D.; Picchio, S.; Sterlich, C.D.; Mangoni, A.; Tullio, G.D.; Costantino, V.; Lega, M. Cyanobacteria as indicators of water quality in Campania coasts, Italy: A monitoring strategy combining remote/proximal sensing and in situ data. Environ. Res. Lett. 2017, 12, 024001. [CrossRef]

9. Esposito, G.; Teta, R.; Marrone, R.; De Sterlich, C.; Casazza, M.; Anastasio, A.; Lega, M.; Costantino, V. A Fast Detection Strategy for Cyanobacterial blooms and associated cyanotoxins (FDSCC) reveals the occurrence of lyngbyatoxin A in campania (South Italy). Chemosphere 2019, 225, 342-351. [CrossRef]

10. Rezanka, T.; Dembitsky, V.M. Metabolites produced by cyanobacteria belonging to several species of the family Nostocaceae. Folia Microbiol. (Praha) 2006, 51, 159-182. [CrossRef]

11. Tan, L.T. Filamentous tropical marine cyanobacteria: A rich source of natural products for anticancer drug discovery. J. Appl. Phycol. 2010, 22, 659-676. [CrossRef]

12. Jones, A.C.; Monroe, E.A.; Podell, S.; Hess, W.R.; Klages, S.; Esquenazi, E.; Niessen, S.; Hoover, H.; Rothmann, M.; Lasken, R.S.; et al. Genomic insights into the physiology and ecology of the marine filamentous cyanobacterium Lyngbya majuscula. Proc. Natl. Acad. Sci. USA 2011, 108, 8815-8820. [CrossRef] [PubMed]

13. Nunnery, J.K.; Mevers, E.; Gerwick, W.H. Biologically active secondary metabolites from marine cyanobacteria. Curr. Opin. Biotechnol. 2010, 21, 787-793. [CrossRef] [PubMed]

14. Zanchett, G.; Oliveira-Filho, E.C. Cyanobacteria and cyanotoxins: From impacts on aquatic ecosystems and human health to anticarcinogenic effects. Toxins (Basel) 2013, 5, 1896-1917. [CrossRef] [PubMed]

15. Caso, A.; Esposito, G.; Della Sala, G.; Pawlik, J.R.; Teta, R.; Mangoni, A.; Costantino, V. Fast Detection of Two Smenamide Family Members Using Molecular Networking. Mar. Drugs 2019, 17, 618. [CrossRef] [PubMed]

16. Mohimani, H.; Gurevich, A.; Mikheenko, A.; Garg, N.; Nothias, L.F.; Ninomiya, A.; Takada, K.; Dorrestein, P.C.; Pevzner, P.A. Dereplication of peptidic natural products through database search of mass spectra. Nat. Chem. Biol. 2017, 13, 30-37. [CrossRef] [PubMed]

17. Mohimani, H.; Gurevich, A.; Shlemov, A.; Mikheenko, A.; Korobeynikov, A.; Cao, L.; Shcherbin, E.; Nothias, L.F.; Dorrestein, P.C.; Pevzner, P.A. Dereplication of microbial metabolites through database search of mass spectra. Nat. Commun. 2018, 9, 4035. [CrossRef] 
18. Quinn, R.A.; Nothias, L.F.; Vining, O.; Meehan, M.; Esquenazi, E.; Dorrestein, P.C. Molecular Networking As a Drug Discovery, Drug Metabolism, and Precision Medicine Strategy. Trends Pharm. Sci. 2017, 38, 143-154. [CrossRef]

19. Harada, K.-i.; Fujii, K.; Shimada, T.; Suzuki, M.; Sano, H.; Adachi, K.; Carmichael, W.W. Two cyclic peptides, anabaenopeptins, a third group of bioactive compounds from the cyanobacterium Anabaena flos-aquae NRC 525-17. Tetrahedron Lett. 1995, 36, 1511-1514. [CrossRef]

20. Welker, M.; von Dohren, H. Cyanobacterial peptides - nature's own combinatorial biosynthesis. Fems. Microbiol. Rev. 2006, 30, 530-563. [CrossRef]

21. Rounge, T.B.; Rohrlack, T.; Nederbragt, A.J.; Kristensen, T.; Jakobsen, K.S. A genome-wide analysis of nonribosomal peptide synthetase gene clusters and their peptides in a Planktothrix rubescens strain. BMC Genom. 2009, 10, 396. [CrossRef]

22. Christiansen, G.; Philmus, B.; Hemscheidt, T.; Kurmayer, R. Genetic Variation of Adenylation Domains of the Anabaenopeptin Synthesis Operon and Evolution of Substrate Promiscuity. J. Bacteriol. 2011, 193, 3822. [CrossRef]

23. Rouhiainen, L.; Jokela, J.; Fewer, D.P.; Urmann, M.; Sivonen, K. Two alternative starter modules for the non-ribosomal biosynthesis of specific anabaenopeptin variants in Anabaena (Cyanobacteria). Chem. Biol. 2010, 17, 265-273. [CrossRef] [PubMed]

24. Koketsu, K.; Mitsuhashi, S.; Tabata, K. Identification of homophenylalanine biosynthetic genes from the cyanobacterium Nostoc punctiforme PCC73102 and application to its microbial production by Escherichia coli. Appl. Env. Microbiol. 2013, 79, 2201-2208. [CrossRef]

25. Lima, S.; Alvarenga, D.; Etchegaray, A.; Fewer, D.; Jokela, J.; Varani, A.; Sanz, M.; Dörr, F.; Pinto, E.; Sivonen, K.; et al. Genetic Organization of Anabaenopeptin and Spumigin Biosynthetic Gene Clusters in the Cyanobacterium Sphaerospermopsis torques-reginae ITEP-024. Acs Chem. Biol. 2017, 12, 769-778. [CrossRef]

26. Alvarenga, D.O.; Franco, M.W.; Sivonen, K.; Fiore, M.F.; Varani, A.M. Evaluating Eucalyptus leaf colonization by Brasilonema octagenarum (Cyanobacteria, Scytonemataceae) using in planta experiments and genomics. PeerJ 2020, 8, e9158. [CrossRef]

27. Fiore, M.F.; Sant'Anna, C.L.; Azevedo, M.T.d.P.; Komárek, J.; Kaštovský, J.; Sulek, J.; Lorenzi, A.S. The cyanobacterial genus Brasilonema, gen. Nov., a molecular and phenotypic evaluation. J. Phycol. 2007, 43, 789-798. [CrossRef]

28. Vaccarino, M.A.; Johansen, J.R. Brasilonema angustatum sp. Nov. (nostocales), a new filamentous cyanobacterial species from the hawaiian islands. J. Phycol. 2012, 48, 1178-1186. [CrossRef]

29. Villanueva, C.D.; Hašler, P.; Dvořák, P.; Poulíčková, A.; Casamatta, D.A. Brasilonema lichenoides sp. nov. and Chroococcidiopsis lichenoides sp. nov. (Cyanobacteria): Two novel cyanobacterial constituents isolated from a tripartite lichen of headstones. J. Phycol. 2018, 54, 224-233. [CrossRef]

30. Sanz, M.; Andreote, A.P.; Fiore, M.F.; Dorr, F.A.; Pinto, E. Structural Characterization of New Peptide Variants Produced by Cyanobacteria from the Brazilian Atlantic Coastal Forest Using Liquid Chromatography Coupled to Quadrupole Time-of-Flight Tandem Mass Spectrometry. Mar. Drugs 2015, 13, 3892-3919. [CrossRef]

31. Schmidt, E.W.; Harper, M.K.; Faulkner, D.J. Mozamides A and B, Cyclic Peptides from a Theonellid Sponge from Mozambique. J. Nat. Prod. 1997, 60, 779-782. [CrossRef]

32. Blin, K.; Shaw, S.; Steinke, K.; Villebro, R.; Ziemert, N.; Lee, S.Y.; Medema, M.H.; Weber, T. antiSMASH 5.0: Updates to the secondary metabolite genome mining pipeline. Nucleic Acids Res. 2019, 47, W81-W87. [CrossRef] [PubMed]

33. Luesch, H.; Hoffmann, D.; Hevel, J.M.; Becker, J.E.; Golakoti, T.; Moore, R.E. Biosynthesis of 4-methylproline in cyanobacteria: Cloning of nosE and nosF genes and biochemical characterization of the encoded dehydrogenase and reductase activities. J. Org. Chem 2003, 68, 83-91. [CrossRef] [PubMed]

34. Hoffmann, D.; Hevel, J.M.; Moore, R.E.; Moore, B.S. Sequence analysis and biochemical characterization of the nostopeptolide A biosynthetic gene cluster from Nostoc sp. GSV224. Gene 2003, 311, 171-180. [CrossRef]

35. D'Agostino, P.M.; Gulder, T.A.M. Direct Pathway Cloning Combined with Sequence- and Ligation-Independent Cloning for Fast Biosynthetic Gene Cluster Refactoring and Heterologous Expression. Acs Synth. Biol. 2018, 7, 1702-1708. [CrossRef] 
36. May, D.S.; Chen, W.L.; Lantvit, D.D.; Zhang, X.; Krunic, A.; Burdette, J.E.; Eustaquio, A.; Orjala, J. Merocyclophanes C and D from the Cultured Freshwater Cyanobacterium Nostoc sp. (UIC 10110). J. Nat. Prod. 2017, 80, 1073-1080. [CrossRef]

37. Gesner-Apter, S.; Carmeli, S. Protease inhibitors from a water bloom of the cyanobacterium Microcystis aeruginosa. J. Nat. Prod. 2009, 72, 1429-1436. [CrossRef]

38. Spoof, L.; Blaszczyk, A.; Meriluoto, J.; Ceglowska, M.; Mazur-Marzec, H. Structures and Activity of New Anabaenopeptins Produced by Baltic Sea Cyanobacteria. Mar. Drugs 2015, 14, 8. [CrossRef]

39. Mares, J.; Hajek, J.; Urajova, P.; Kopecky, J.; Hrouzek, P. A hybrid non-ribosomal peptide/polyketide synthetase containing fatty-acyl ligase (FAAL) synthesizes the beta-amino fatty acid lipopeptides puwainaphycins in the Cyanobacterium Cylindrospermum alatosporum. PLoS ONE 2014, 9, e111904. [CrossRef]

40. Bankevich, A.; Nurk, S.; Antipov, D.; Gurevich, A.A.; Dvorkin, M.; Kulikov, A.S.; Lesin, V.M.; Nikolenko, S.I.; Pham, S.; Prjibelski, A.D.; et al. SPAdes: A new genome assembly algorithm and its applications to single-cell sequencing. J. Comput. Biol. 2012, 19, 455-477. [CrossRef]

41. Parks, D.H.; Imelfort, M.; Skennerton, C.T.; Hugenholtz, P.; Tyson, G.W. CheckM: Assessing the quality of microbial genomes recovered from isolates, single cells, and metagenomes. Genome Res. 2015, 25, 1043-1055. [CrossRef] [PubMed]

42. Kessner, D.; Chambers, M.; Burke, R.; Agus, D.; Mallick, P. ProteoWizard: Open source software for rapid proteomics tools development. Bioinformatics 2008, 24, 2534-2536. [CrossRef] [PubMed]

43. Wang, M.; Carver, J.J.; Phelan, V.V.; Sanchez, L.M.; Garg, N.; Peng, Y.; Nguyen, D.D.; Watrous, J.; Kapono, C.A.; Luzzatto-Knaan, T.; et al. Sharing and community curation of mass spectrometry data with Global Natural Products Social Molecular Networking. Nat. Biotechnol. 2016, 34, 828-837. [CrossRef] [PubMed]

44. Saurav, K.; Borbone, N.; Burgsdorf, I.; Teta, R.; Caso, A.; Bar-Shalom, R.; Esposito, G.; Britstein, M.; Steindler, L.; Costantino, V. Identification of Quorum Sensing Activators and Inhibitors in The Marine Sponge Sarcotragus spinosulus. Mar. Drugs 2020, 18, 127. [CrossRef]

45. Mosmann, T. Rapid colorimetric assay for cellular growth and survival: Application to proliferation and cytotoxicity assays. J. Immunol. Methods 1983, 65, 55-63. [CrossRef]

Sample Availability: Samples of the crude extracts from Brasilonema sp. CT11 and compounds anabaenopeptin $802 \mathrm{a}$ and anabaenopeptin $802 \mathrm{~b}$ are available from the authors.

(C) 2020 by the authors. Licensee MDPI, Basel, Switzerland. This article is an open access article distributed under the terms and conditions of the Creative Commons Attribution (CC BY) license (http://creativecommons.org/licenses/by/4.0/). 